\title{
Joubert syndrome and related disorders
}

\section{Zespół Joubert i schorzenia pokrewne}

\author{
Justyna Paprocka, Ewa Jamroz \\ Child Neurology Department, Silesian Medical University, Katowice, Poland
}

Neurologia i Neurochirurgia Polska 2012; 46, 4: 379-383

DOl: 10.5114/ninp.2012.30457

\begin{abstract}
The cerebellum plays a role not only in motor control but also in motor learning and cognition. Joubert syndrome is a rare heterogeneous inherited genetic disorder characterized by ataxia, hypotonia, developmental delay, and at least one of the following features: neonatal respiratory disturbances or abnormal eye movement. The estimated frequency of Joubert syndrome in the United States is around $1: 100$ 000. The term Joubert syndrome and related disorders (JSRD) has been recently coined to describe all disorders presenting with molar tooth sign on brain neuroimaging. Joubert syndrome is believed to be a representative of a new group of disorders named ciliopathies. The identification of seven causal genes (NPHP1, AHI1, CEP290, RPGRIP1L, TMEM67/MKS3, $A R L 13 B, C C 2 D 2 A)$ has led to substantial progress in the understanding of the genetic basis of Joubert syndrome. The authors focus on clinical presentation of JSRD, differential diagnosis and molecular background.
\end{abstract}

Key words: Joubert syndrome, children, classification, clinical presentation.

\section{Classification of Joubert syndrome and related disorders (JSRD)}

Marie Joubert, a French neurologist, was the first to report Joubert syndrome (OMIM 213 300) in five patients who presented breathing disorders and abnormal

\section{Streszczenie}

Móżdżek odgrywa istotną rolę w kontroli nie tylko funkcji ruchowych, ale także procesów poznawczych. Zespół Joubert jest rzadkim heterogennym schorzeniem uwarunkowanym genetycznie, charakteryzującym się występowaniem ataksji, hipotonii, opóźnienia rozwoju psychoruchowego, a także jednej z następujących cech: zaburzeń oddychania w okresie noworodkowym lub nieprawidłowych ruchów gałek ocznych. Szacowana częstość występowania zespołu Joubert i zespołów pokrewnych w USA wynosi ok. 1 : 100 000. Zespół Joubert i zespoły pokrewne obejmują schorzenia, w których występuje obraz „zęba trzonowego” w badaniu obrazowym układu nerwowego. Zespół Joubert stanowi przykład nowej grupy chorób nazywanych ciliopatiami. Identyfikacja 7 genów (NPHP1, AHI1, CEP290, RPGRIP1L, TMEM67/MKS3, ARL13B, $C C 2 D 2 A)$ poczyniła znaczący postęp w zrozumieniu genetycznych podstaw zespołu Joubert. Autorzy prezentują objawy kliniczne zespołu Joubert i schorzeń pokrewnych, diagnostykę różnicową i podłoże genetyczne.

Słowa kluczowe: zespół Joubert, dzieci, klasyfikacja, obraz kliniczny.

eye movements, ataxia, and mental retardation associated with agenesis of the cerebellar vermis [1]. Maria et al. proposed the diagnostic criteria for Joubert syndrome: hypotonia, ataxia, developmental delay and 'molar tooth sign' $[1,2]$. The detailed classification of JSRD is presented in Table 1 [3-7].

Correspondence address: Justyna Paprocka, Child Neurology Department, Medical University of Silesia, ul. Medyków 16, 40-752 Katowice, Poland, phone: + 4832207 16 00,fax: +48 32207 16 15, e-mail: justyna.paprocka@interia.pl

Received: 16.04.2011; accepted: 21.09.2011 
Table 1. Classification of Joubert syndrome [3-12]

\begin{tabular}{|c|c|c|c|}
\hline Clinical subtypes & Main features & Associated features & Molecular background \\
\hline Pure Joubert syndrome (JS) & molar tooth sign & & $\begin{array}{l}\text { mutation in many genes: } \\
\text { JBTS1/INPP5E (9q34.3), } \\
\text { JBTS2/TMEM216 (11q13), } \\
\text { JBTS3/AHI1 (6q 23), } \\
\text { JBTS4/NPHP1 (2q13), } \\
\text { JBTS5/CEP290 (12q21,32), } \\
\text { JBTS6/TMEM67 (8q21), } \\
\text { JBTS7/RPGRIPIL (16q12.2), } \\
\text { JBTS8/ARL13B (3q11.2), } \\
\text { JBTS9/CC2D2A (4p15.3), } \\
\text { JBTS10/OFD1 (Xp22.3) }\end{array}$ \\
\hline $\begin{array}{l}\text { Joubert syndrome with } \\
\text { ocular defect (JS-O) }\end{array}$ & $\begin{array}{l}\text { molar tooth sign, retinal } \\
\text { dystrophy, including Leber } \\
\text { congenital amaurosis }\end{array}$ & & AHII \\
\hline $\begin{array}{l}\text { Joubert syndrome with } \\
\text { renal defect (JS-R) }\end{array}$ & $\begin{array}{l}\text { molar tooth sign, } \\
\text { nephronophthisis (renal } \\
\text { fibrocystic disease) }\end{array}$ & & $\begin{array}{l}\text { NPHP1 } \\
\text { RPGRIP1L }\end{array}$ \\
\hline $\begin{array}{l}\text { Joubert syndrome with } \\
\text { oculorenal defects (JS-OR) }\end{array}$ & $\begin{array}{l}\text { molar tooth sign retinal } \\
\text { dystrophy (often with Leber } \\
\text { congenital amaurosis), } \\
\text { nephronophthisis }\end{array}$ & $\begin{array}{l}\text { in some patients } \\
\text { - congenital hepatic fibrosis }\end{array}$ & CEP290 \\
\hline $\begin{array}{l}\text { Joubert syndrome with } \\
\text { hepatic defect (JS-H) }\end{array}$ & $\begin{array}{l}\text { molar tooth sign, congenital } \\
\text { hepatic fibrosis }\end{array}$ & $\begin{array}{l}\text { colobomas, } \\
\text { nephronophthisis }\end{array}$ & TMEM67 \\
\hline $\begin{array}{l}\text { Joubert syndrome with } \\
\text { oro-facio-digital defects } \\
\text { (JS-OFD) }\end{array}$ & $\begin{array}{l}\text { molar tooth sign, } \\
\text { lobulated/bifid tongue } \\
\text { (including hamartomas), } \\
\text { polydactyly }\end{array}$ & cleft lip/palate & TMEM216 \\
\hline
\end{tabular}

\section{Clinical presentation}

The typical dysmorphic features in Joubert syndrome include prominent forehead, upturned nose, and open mouth. The main neurological symptoms in JSRD are hypotonia, ataxia, developmental delay, intellectual disability, and abnormal ocular movements [5-8]. Epileptic seizures in association with Joubert syndrome are very rare (3\%) [3-6]. In the neonatal period there is an altered respiratory pattern with episodes of apnea and hyperpnea or episodes of hyperpnea alone. These symptoms can range from short intervals to pronged attacks requiring assisted ventilation. They usually improve with age and disappear around the sixth month of life. Abnormal eye movements comprise oculomotor apraxia, primary position nystagmus, and occasionally strabismus or ptosis $[7,8,13]$.

All patients diagnosed with JSRD have developmental/intellectual disability. Reported developmental and intelligence quotients are usually between 30 and 80 $[4,7]$. The major abnormality in JSRD is in the cerebel- lum. However, accompanying abnormalities of the brainstem (as known in Joubert syndrome) and/or cerebrum might also have an influence on cognitive functions. Thus, the cerebellar role for the cognitive problems in these children seems to be important, but additional cerebral dysfunction cannot be ruled out. Although cerebellar contribution to cognitive problems is strongly suggested by volumetric and structural abnormalities, a secondary transsynaptic effect on the cerebellum by abnormalities/ dysfunction of other cerebral regions has to be considered $[14,15]$. A transsynaptic effect, however, cannot explain all findings; a model with a disturbed interplay between cerebellum and cerebrum might explain the cognitive dysfunction observed in these children [14].

Another organ frequently involved in JSRD is the retina. In Leber congenital amaurosis, the clinical presentation may range from cortical blindness to retinal dystrophy with different course and different degree of preserved vision [5-7]. A rare cause of visual disturbances described in JSRD is coloboma; its frequency rises to $30 \%$ in Joubert syndrome with hepatic defect $[13,15]$. 
Renal disorders affect almost 25\% of patients with JSRD [13]. Saraiva et al. reported renal abnormalities in 30\% of cases and Doherty found them in about 23\% of patients $[5,6,16]$. In most cases, they present as a structural tubule-intestinal disease with irregular, thickened basal membrane or a tubular epithelium, progressive interstitial fibrosis and small cysts at the corticomedullary junction. The first symptoms of isolated nephronophthisis (NPH) may remain unrecognized and manifest as polyuria and polydipsia. In the late first decade of life, acute or chronic renal insufficiency occurs. In some patients renal disease may manifest as cystic dysplastic kidney. Such abnormality may also be observed in DekabanArima syndrome and in Meckel syndrome [3-5].

Congenital hepatic fibrosis present in a minority of patients with JSRD results from malformation of the ductal plate with cystic dilatation of biliary structures and fibrous enlargement of the portal tracts. The disease may manifest with elevated liver enzymes, hepatosplenomegaly or even portal hypertension, esophageal varices and endstage liver cirrhosis [3,5,7-9].

The most often reported skeletal abnormality is postaxial polydactyly with a frequency of about 8-16\% [4,7]. With age, scoliosis may appear, which is likely to correlate with the degree of hypotonia and require monitoring during puberty.

\section{Neuroimaging studies}

'Molar tooth sign' (on axial magnetic resonance imaging of the pons) depends on a specific malformation of the brainstem and cerebellum, characterized by deepened interpeduncular fossa, hypoplasia of the vermis and thickened and elongated superior cerebellar peduncles [3-9]. Such abnormalities correspond with severe hypoplasia/ dysplasia of the cerebellar vermis with midline clefting, fragmentation of cerebellar nuclei and heterotopias of Purkinje-like neurons, along with dysplasia of pontine and medullary structures such as the basis pontis, reticular formation, inferior olivary, dorsal column and solitary tract nuclei $[17,18]$.

Other central nervous system malformations affecting the outcome and prognosis have been described. Hydrocephalus, abnormalities of the corpus callosum, white matter cysts, hypothalamic hamartomas, absence of the pituitary gland, migration defects, cortical organization defects (polymicrogyria), and meningoencephalocele have been reported [16,17]. Approximately $10 \%$ of individuals with Joubert syndrome have abnor- mal collections of cerebrospinal fluid in the posterior fossa that may resemble Dandy-Walker malformation $[4,5,7]$. According to Doherty et al., the brain malformation in Joubert syndrome comprises at least several components: decreased vermis size with probably decreased cell numbers, aberrant axonal path finding (disrupted decussation of the superior cerebellar peduncles and pyramids), possible abnormal neuronal migration (fragmented dentate nuclei, cerebellar and cortical heterotopias, pachygyric inferior olives) $[5,6]$.

\section{Genetic backgrounds}

The genes recognized in JSRD encode mediators of signal transduction pathways at the primary cilium. In the cerebellum, primary cilia have been identified in both Purkinje cell and granule cell progenitors. There are two theories explaining the vermis hypoplasia in Joubert syndrome [8-12]. Decreased granule cell proliferation results in vermis hypoplasia, possibly due to aberrant sonic hedgehog $(\mathrm{SHH})$ signaling through defective cilia. According to the second one, there are subtle alterations in specification of the mid-hindbrain boundary and rhombomere identities.

Recent advances in genetic testing have revealed that approximately $25 \%$ of patients with either classic Joubert syndrome or JSRD have a mutation in the AHI1 or the CEP290/NPHP6 genes [8-12]. All of the genes involved in JSRD pathology have been associated with the primary cilium and basal body, which allows Joubert syndrome to be included in the group of disorders named ciliopathies [18-21]. Genetic testing for JSRD is based on genotypephenotype correlations and can be prioritized based on clinical features. According to Doherty et al., patients with Joubert syndrome and liver disease should be tested for TMEM6 mutations followed by CC2D2A and RPGRIP1L [5,6]. Retinal and renal abnormalities should be checked for CEP290 mutations. Isolated renal disease should prompt RPGRIP1L testing and isolated retinal abnormalities should prompt testing for $A H I 1$ followed by CEP290 [9-12].

\section{Differential diagnosis}

Molar tooth sign may also be seen in cerebello-oculo-renal syndrome, Dekaban-Arima syndrome, $\mathrm{COACH}$ syndrome (cerebellar vermis hypoplasia, oligophrenia, ataxia, coloboma, hepatic fibrosis), Varadi-Papp syndrome (cerebellar vermis hypoplasia, oral frenula, tongue hamar- 
Table 2. Differential diagnosis of JS and JSRD

\begin{tabular}{|c|c|c|}
\hline Disease & Clinical presentation & Molecular basis \\
\hline Dandy-Walker malformation & $\begin{array}{l}\text { cerebellar hypoplasia of the vermis and/or hemispheres with an enlarged } \\
\text { retrocerebellar cerebrospinal fluid collection continuous with the fourth } \\
\text { ventricle, agenesis or hypoplasia of the corpus callosum and hydrocephalus; } \\
\text { delayed motor development, hypotonia, and ataxia }\end{array}$ & $3 \mathrm{q} 24$ \\
\hline X-linked cerebellar hypoplasia & $\begin{array}{l}\text { hypotonia at birth and moderate mental retardation, ataxia, macrocephaly, } \\
\text { seizures, strabismus and genital hypoplasia }\end{array}$ & Xp11.21-q21.3 \\
\hline $\begin{array}{l}\text { ataxia and oculomotor apraxia } \\
\text { type } 1 \text { (AOA1) } \\
\text { ataxia and oculomotor apraxia } \\
\text { type } 2 \text { (AOA2) }\end{array}$ & $\begin{array}{l}\text { childhood-onset progressive cerebellar ataxia, cerebellar atrophy, } \\
\text { oculomotor apraxia, peripheral neuropathy, mental retardation }\end{array}$ & $9 \mathrm{p} 13.3$ \\
\hline $\begin{array}{l}\text { congenital disorders } \\
\text { of glycosylation }\end{array}$ & delays in development, hypotonia, ataxia, and strabismus & $\begin{array}{l}\text { different genetic } \\
\text { loci }\end{array}$ \\
\hline $\begin{array}{l}\text { 3-C syndrome } \\
\text { (cranio-cerebello-cardiac } \\
\text { syndrome, Ritscher-Schinzel } \\
\text { syndrome) }\end{array}$ & $\begin{array}{l}\text { cardiac malformation, cerebellar malformation, cleft palate } \\
\text { or ocular coloboma or four of the following seven findings: } \\
\text { prominent forehead, prominent occiput, hypertelorism, } \\
\text { down-slanting palpebral fissures, low-set ears, depressed } \\
\text { nasal bridge, and micrognathia }\end{array}$ & $\begin{array}{l}\text { unidentified gene } \\
\text { locus }\end{array}$ \\
\hline $\begin{array}{l}\text { pontocerebellar } \\
\text { hypoplasias/atrophies type } 1 \text {, } \\
2 \mathrm{~A}-\mathrm{C}, 3,4,5,6\end{array}$ & cerebellar vermis hypoplasia, hypoplasia of the pons & $\begin{array}{l}1-14 \mathrm{q} 32 \\
2-17 \mathrm{q} 25.1 \\
3 \mathrm{p} 25.1 ; 19 \mathrm{q} 13.4 \\
3-7 \mathrm{q} 11-\mathrm{q} 21 \\
4-17 \mathrm{q} 25.1 \\
6-6 \mathrm{q} 16.1\end{array}$ \\
\hline $\begin{array}{l}\text { oro-facio-digital (OFD) } \\
\text { syndromes: II (Mohr } \\
\text { syndrome) and III }\end{array}$ & $\begin{array}{l}\text { OFD II: tongue tumors with abnormal frenula, midline facial } \\
\text { clefts, polydactyly, cerebellar vermis agenesis } \\
\text { OFD III: mental retardation and postaxial polydactyly }\end{array}$ & $\begin{array}{l}\text { unidentified gene } \\
\text { locus }\end{array}$ \\
\hline Meckel-Gruber syndrome & $\begin{array}{l}\text { occipital encephalocele, polydactyly, polycystic kidneys, liver } \\
\text { developmental defects (hepatic fibrosis, bile duct proliferation, } \\
\text { ductal plate malformation) }\end{array}$ & \\
\hline
\end{tabular}

tomas, and midline cleft lip, as well as the distinctive feature of central polydactyly with a Y-shaped metacarpal), Malta syndrome, Senior-Loken syndrome (retinopathy and juvenile-onset nephronophthisis), and Bardet-Biedl syndrome $[3-5,7,15,16]$.

Other conditions to consider in the differential diagnosis of Joubert syndrome are those with cerebellar vermis hypoplasia or dysgenesis without the molar tooth sign on MRI: Dandy-Walker malformation, $\mathrm{X}$-linked cerebellar hypoplasia, ataxia and oculomotor apraxia type 1 (AOA1) and ataxia and oculomotor apraxia type 2 (AOA2), congenital disorders of glycosylation (CDG), 3-C syndrome (cranio-cerebello-cardiac syndrome, Ritscher-Schinzel syndrome), the pontocerebellar hypoplasias/atrophies, oral-facial-digital (OFD) syndromes II and III, and Meckel-Gruber syndrome $[15,16]$ (Table 2).

\section{Prognosis}

The prognosis of Joubert syndrome is poor. The 5 -year survival is about $50 \%[3-7,15]$. Once the diagnosis of Joubert syndrome is made, it is recommended to perform a comprehensive functional and morphological examination of the liver and kidney. Ophthalmologic evaluation for visual acuity, tracking ability, and development of retinal dystrophy should be performed in all patients with JSRD, especially in individuals with $A H I 1$ or CEP290 mutations, because they are at high risk for retinal dystrophy [9-12]. It is well known that clinical features may vary between and within the same family due to genetic heterogeneity and phenotype diversity. Despite the remarkable advances in the genetics of Joubert syndrome and related disorders, little is known about how the gene defects may influence brain function, development and structures $[18,19,21]$. 


\section{Disclosure}

Authors report no conflict of interest.

\section{References}

1. Joubert M., Eisenring J.J., Robb J.P., et al. Familial agenesis of the cerebellar vermis. A syndrome of episodic hyperpnea, abnormal eye movements, ataxia and retardation. Neurology 1969; 19: 813-825.

2. Bolthauser E., Isler W. Joubert syndrome. Episodic hyperpnea, abnormal eye movements, retardation and ataxia, associated with dysplasia of the cerebellar vermis. Neuropediatrics 1977; 8: 57-66.

3. Maria B.L., Boltshauser E., Palmer S.C., et al. Clinical features and revised diagnostic criteria in Joubert syndrome. J Child Neurol 1999; 14: 583-590.

4. Brancatti F., Dallapiccola B., Valente E. Joubert syndrome and related disorders. OJRD 2010; 5: 20-30.

5. Parisi M.A., Doherty D., Chance P.F., et al. Joubert syndrome (and related disorders). Eur J Hum Genet 2007; 15: 511-521.

6. Doherty D. Joubert syndrome: insights into brain development, cilium biology, and complex disease. Sem Pediatr Neurol 2009; 16: 143-154.

7. Hodgkins P.R., Harris C.M., Shawkat F.S., et al. Joubert's syndrome. Long term follow-up. Dev Med Child Neurol 2004; 46: 694-699.

8. Valente F.M., Marsh S.E., Castori M., et al. Distinguishing the four genetic causes of Joubert syndrome-related disorders. Ann Neurol 2005; 57: 513-519.

9. Parrault I., Delphin N., Hanein S., et al. Spectrum of NPHP6/ CEP290 in mutations in Leber's congenital amaurosis and delineation of the associated phenotype. Hum Mutat 2007; 28: 416.

10. Cantagrel V., Silhavy J.L., Bielas S.L., et al. Mutations in the cilia gene ARL13B lead to classical form of Joubert's syndrome. Am J Hum Genet 2008; 83: 170-179.

11. Brancati F., Barrano G., Silhavy J.L., et al. CEP290 mutations are frequently identified in the oculo-renal form of Joubert's syndrome-related disorders. Am J Hum Genet 2007; 81: 104-113.

12. Parisi M.A., Doherty D., Eckert M.L., et al. AHI1 mutations cause both retinal dystrophy and renal cystic disease in Joubert's syndrome. J Med Genet 2006; 43: 334-339.

13. Khan A.O., Oystreck D.T., Seidahmed M.Z., et al. Ophthalmic features of Joubert's syndrome. Ophthalmology 2008; 115: 2286-2289.

14. Tavano A., Borgatti R. Evidence for a link among cognition, language and emotion in cerebellar malformations. Cortex 2010; 46: 907-918.

15. Leao E.E., Lima M.M., Parizotto J., et al. Joubert syndrome. Large clinical variability and a unique neuroimaging aspect. Arq Neuropsiquiatr 2010; 68: 273-276.

16. Saraiva J.M., Baraitser M. Joubert syndrome: a review. Am J Med Genet 1992; 43: 726-731

17. Gleeson J.G., Keeler L.C., Parisi M.A., et al. Molar tooth sign of the midbrain-hindbrain junction: occurrence in multiple distinct syndromes. Am J Med Genet 2004; 125A: 125-134.

18. Kuchukhindze G., Rauchenzauner M., Gotwald T., et al. Hypoplasia of deep cerebellar nuclei in Joubert syndrome. Pediatr Neurol 2009; 40: 474-476.
19. Donkelaar H.J., Lammens M. Development of the human cerebellum and its disorders. Perinatology 2009; 36: 513-530.

20. Badano J.L., Mitsuma N., Beales P.L., et al. The ciliopathies: an emerging class of human genetic disorders. Ann Rev Genom Hum Genet 2006; 7: 125-148.

21. Gorden N.T., Arts H.H., Parisi M.A., et al. CC2D2A is mutated in Joubert's syndrome and interacts with the ciliopathy-associated basal body protein CEP290. Am J Hum Genet 2008; 83: 559-571.

22. Wong S.Y., Reiter J.F. The primary cilium at the crossroads of mammalian hedgehog signaling. Curr Top Dev Biol 2008; 85: 225-260. 